\title{
Antioxidative and antiapoptotic effects of vitamin A and vitamin C against carbon tetrachloride induced hepatotoxicity in mice
}

\author{
Sohair A Hassan*, Mahmoud M Salem** And olfat hamam*** \\ *Medicinal Chemistry Department, National Research Center, Cairo, Egypt. \\ **Zoology department, College of Science, Al-Azhar University, Cairo, Egypt \\ ***Pathology DepartementTheodore Bilhars Institute Cairo, Egypt*
}

\begin{abstract}
Reactive oxygen radicals play an important role in various forms of liver injury. The present study was a trial to evaluate the efficacy of each of vitamin A\&C in its clinical dose ( $80 \mathrm{mg} / \mathrm{Kg}$ ip) on experimental model of chronic liver injury in mice using carbon tetrachloride (CCl4). Animals were subdivided into four groups (control, $\mathrm{CCl} 4$ treated, $\mathrm{CCl} 4+\mathrm{Vit}$.A and $\mathrm{CCl} 4+\mathrm{Vit} . \mathrm{C}$ ). Vitamin A\&C were administrated 2 hours prior interaperitoneal administration of $0.2 \mathrm{ml} / \mathrm{Kg} \mathrm{CCl} 4$ in mice. A significant decrease in serum Glutathione (GSH) and Superoxide dismutase (SOD) activity along with marked elevation of serum malondialdehyde (MDA), aspartate aminotransferase (AST) and alanine aminotransferase (ALT) was recorded in response to $\mathrm{CCl} 4$ hepatotoxicity. An notable normalizing to this measured parameters was observed in the groups treated by vitamin A \& C. On Histopathological basis, hydropic degeneration, steatotic changes and apoptosis was seen obviously in $\mathrm{CCl} 4$ treated group but partial improvement in the previous parameters was noted in vitamin $\mathrm{A} \& \mathrm{C}$ treated groups in spite of vitamin $\mathrm{C}$ seemed to be less effective as far as vitamin A. These results theorized that vitamin A \& $\mathrm{C}$ may have a potency to increase the antioxidant and antiapoptotic defense system activity in the $\mathrm{CCl} 4$ treated mice.
\end{abstract}

\section{Introduction}

Hepatotoxins namely carbon tetrachloride (CCl4) induces acute hepatic necrosis, fatty degeneration, advanced fibrosis and many other significant alteration in liver enzymes activities (Turkdo et al., 2001\& Nakamoto et al., 2003).

A significant elevation in the activities of ALT, AST, alkaline phosphatase (AP) and serum bilirubin was recorded by Datta et al. (1998) following $\mathrm{CCl} 4$ hepatotoxicity.

In addition to the above variables, lactate dehydrogenase (LDH) elevation, significant decrease in total sulphydryl (-SH) content and catalase activity in hepatic tissues and also a significant increase in lipid peroxidation measured as malondialdhyde (MDA) were consi-

dered evidences for $\mathrm{CCl} 4$ hepatotoxicity in mice (Mansour, 2000).

$\mathrm{CCl} 4$ hepatotoxicity is mainly caused by increase the production of oxygen free radicals that causes lipid peroxidation. Kamataki et al (1977) found that oral administration of $\mathrm{CCl} 4$ to rats inhibited microsomal NADPHdependent lipid peroxidation.

Weber et al. (2003) suggested that CCL4 is activated by cytochrome (cyp) $2 \mathrm{E} 1$ or cyp2B2 and possibly cyp3A to form the trichloromethyl radical, CCL3. This radical can bind to cellular molecules (nucleic acid, protein, lipid) impairing crucial cellular processes such as lipid metabolism, with the potential outcome of fatty degeneration (steatosis). 
The protective effects of some antioxidant treatments on $\mathrm{CCl} 4$ liver toxicity was studied by many authors (Cajanus indicus derivative (Datta et al, 1998); Colchicines (Mizuoka et al, 1999); Vitamin E (Mustafa Naziroglu et al, 1999); Thymoquinone and Desferrioxamine (Mansour, 2000); Captopril (El-Khatib and Mansour, 2001); PMC, a derivative of alphatocopherol (Hsiao et al., 2001); Vitamin C\&E, selenium and Nigella sativa (Turkdo et al, 2001); volatile oil constituent of Nigella sativa, Thymoquinone, Pcymene and alphapinene (Mansour et al., 2001); total flavonoids of Astragalus (Wang et al., 2001); Salacia reticulata extracts (Yoshikawa et al, 2002); Aquilegia vulgaris extracts (Adamska et al., 2003); Antrodia camphorata extract (Hsiao et al., 2003); and Gossypitrin (Perez et al., 2003).

This study was designed to investigate the antioxidative $\&$ antiapoptotic effects of vitamin $\mathrm{A}$ and vitamin $\mathrm{C}$ on lipid peroxidation, antioxidant enzyme systems, some liver enzymes activities and liver cell apoptosis in carbon tetrachloride induced hepatotoxic mice.

\section{Material and methods}

\section{The animal grouping and treatments:}

Male Swiss albino mice, weighing 20-25 g kept under good ventilation and balanced diet were used in this study. Animals were subdivided into four groups (15 each). Group 1(control) did not receive any treatment. Group2 received $\mathrm{CCl} 4(0.2 \mathrm{ml} / \mathrm{Kg}$ ip Hewawasam et al 2003) daily for 60 days. Group 3 received vitamin., A (80 mg / $\mathrm{kg}$ ip Tantcheva et al, 2003) $2 \mathrm{hrs}$ prior to CCl4 $(0.2 \mathrm{ml} / \mathrm{kg}$ ip) daily for 60 days. Group 4 received vitamin C $(80 \mathrm{mg} / \mathrm{kg}$ ip Tantcheva et al., 2003) $2 \mathrm{hr}$ prior to CCl4 (0.2ml / kg ip) daily for 60 days.Vitamine $\mathrm{A}$ and $\mathrm{C}$ were supplied by AL Gomhouria co. for pharmaceuticals and chemical industries.

\section{Biochemical analysis:}

Serum samples were prepared through blood centrifugation at 3000 r.p.m for biochemical determinations.

GSH was measured by the procedure of Beutler et al (1963), which is based on extraction of GSH with metaphosphoric acid and then its reaction with dithiobisnitrobenzoic acid (DTNB) to form a yellow color, which is read at $412 \mathrm{~nm}$.

MDA, a product of lipid peroxidation was determined by the method of Begonia et al, (1994) using a saturated solution of thiobarbituric acid and the developed color read at $532 \mathrm{~nm}$.

SOD activity was assayed using a kit obtained from Randox. The method employs xanthine and xanthine oxidase to generate super oxide radicals, which react with 2-(4- iodophenyl)-3(4-nitrophenyl)-5 phenyltetrazolium chloride (I.N.T.) to form a red formazon dye. The SOD activity is then measured by the degree of inhibition of this reaction at $560 \mathrm{~nm}$.

ALT \&AST were estimated colorimetrically using kits from BioMerieux (Marcy 1 Etoile, France)

\section{Histopathological test:}

Mice liver specimens was obtained and fixed in $10 \%$ formaline. Sections were prepared and stained by Fulgen stain for histopathological investigation.

\section{Fulgen stain for liver cells:}

Slides putted in oven for 10 minutes then putted in xylene for 10 minutes, then in a series of alcohols $100 \%, 90 \%$ and $70 \%$ for 5 minutes. The slides were washed by distilled water, rinsed in $5 \mathrm{~N} \mathrm{HCl}$ solution for 50 minutes, and then washed twice by distilled water. Ten drops of schiff 
reagent were added and left to act for 10 minutes, the slides rinsed in sodium metabisulphite solution for 2 minutes then rerinsed in distilled water, again the slides were dehydrated in $70 \%, 90 \%$ and $100 \%$ alcohol and finally mounted by xylene.

\section{Statistical evaluation:}

All calculated data were collected in a database for further statistical evaluation. Using soft ware (SPSS version 9) student " $t$ " test was made to determine the level of significance of difference between different parameters in different groups. Probability values $(\mathrm{P}<0.05)$ were considered significant.

\section{Results}

Results of the effects of vitamin A and vitamin $\mathrm{C}$ administration on serum glutathione (GSH), superoxide dismutase (SOD), Malondialdehyde (MDA), Aspartate aminotransferase (AST) and Alanine aminotransferase (ALT) of $\mathrm{CCl} 4$ induced hepatotoxicity in mice was recorded in table (1) and represented in fig. (1) and (2).

The results show significant decreease $(\mathrm{P}<0.05)$ in serum glutathione (GSH) level of CCI4 treated groups compared to control group, on the other hand significant increase $(\mathrm{P}<0.05)$ was observed in its level in Vitamin A and Vitamin $\mathrm{C}$ administrated groups if compared to $\mathrm{CCl} 4$ group.

Statistical analysis shows significant decrease $(\mathrm{P}<0.05)$ in superoxide dismutase (SOD) activity in $\mathrm{CCl} 4$ compared to control group. In contrast Vitamin $\mathrm{A}$ and Vitamin $\mathrm{C}$ administrated groups showed significant increase $(\mathrm{P}<$ 0.05 ) in its activity if compared to $\mathrm{CCl} 4$ group and no significant difference with control group.

Serum Malondialdehyde (MDA) was significantly increased $(\mathrm{P}<0.05)$ in $\mathrm{CCl} 4$ treated groups compared to control group. Vitamin A supplemented $\mathrm{CCl} 4$ group showed significant decrease $(\mathrm{P}<0.05)$ in serum MDA level in comparison with both $\mathrm{CCl} 4$ treated group and $\mathrm{CCl} 4+$ Vitamin $\mathrm{C}$ group.

$\mathrm{CCl} 4$ induced hepatotoxicity significantly increased $(\mathrm{P}<0.05)$ serum Aspartate aminotransferase (AST) and Alanine aminotransferase (ALT). No significant difference was recorded between $\mathrm{CCl} 4+\mathrm{V}$ it.A group and control group. Vitamin $\mathrm{C}$ markedly decreased the observed elevation in both serum AST and ALT of CCl4 treated groups.

The histopathological effects of $\mathrm{CCl} 4$ and vitamin $\mathrm{A} \& \mathrm{C}$ was studied in the liver of mice and the results are shown in table (2) and fig. (3:7).

Control group (fig. 3) showed well-preserved lobular architecture with almost no pathological changes. It is appeared that mice's treated with $\mathrm{CCl} 4$ (fig. 4) had a loss of lobular architecture (100\% cirrhotic). Mean percent of cirrhotic cells in CCl4+Vit.A group was $65 \%$ while in $\mathrm{CCl} 4+\mathrm{Vit} . \mathrm{C}$ group was $80 \%$.

Hydropic degeneration was recorded in all tested samples of CCl4 treated group with the percentage of $70 \%$. It was found in 12 out of 15 animals of CCl4+Vit.A group (fig. 5) with the percentage of $60 \%$ and in 10 out of 15 animals of $\mathrm{CCl} 4+\mathrm{Vit} . \mathrm{C}$ group (fig. 6) with the percentage of $70 \%$.

A steatotic change was observed in 8 cases out of 15 with the mean percentage of $75 \%$ in $\mathrm{CCl} 4$ treated group. This changes was also found in 7 out of 15 with the percentage of $50 \%$ in CCl4+Vit.A group and in 8 out of 15 in $\mathrm{CCl} 4+\mathrm{Vit} . \mathrm{C}$ group with the percentage of $60 \%$.

The apoptotic changes was found in 8 out of 15 cases with the percentage of $20 \%$ in CCl4 treated group and the apoptotic bodies were found in hepatocytes adjacent to the porbel 
treats. In CCl4+Vit.A group (fig. 7), apoptosis was found takes place in 4 out of 15 cases with the percentage of $10 \%$ and in 7 out of 15 cases with the percentage of $18 \%$ in CCl4+Vit.C group.

Table (1): Effect of Carbon tetrachloride $\left(\mathrm{CCL}_{4}\right)$ hepatotoxicity and the possible role of Vitamin A and Vitamin C supplementation on serum Glutathione (GSH), blood Superoxide dismutase (SOD), serum Malondialdehyde (MDA), Aspartate aminotransferase (AST) and Alanin aminotransferase (ALT) of mice.

\begin{tabular}{|c|c|c|c|c|c|}
\hline & & \multicolumn{4}{|c|}{ Treatment groups } \\
\hline \multicolumn{2}{|l|}{ Parameters } & Control & $\mathrm{CCl}_{4}$ & $\mathrm{CCl}_{4}+\mathrm{Vit} \mathrm{A}$ & $\mathrm{CCl}_{4}+\mathrm{Vit} \mathrm{C}$ \\
\hline \multirow{2}{*}{$\begin{array}{c}\text { Glutahione } \\
(\mathrm{Mg} / \mathrm{dl})\end{array}$} & Mean & 40.54 & $18.68 \mathrm{a}, \mathrm{c}$ & 29.9 a,b,d & $20.78 \mathrm{a}, \mathrm{b}, \mathrm{c}$ \\
\hline & \pm S.D. & 1.22 & 0.7 & 1.1 & 0.89 \\
\hline \multirow{2}{*}{$\begin{array}{c}\text { Superoxide dismutase } \\
(\mathrm{U} / \mathrm{g} \mathrm{Hb})\end{array}$} & Mean & 2437.2 & $1450 \mathrm{a}, \mathrm{c}, \mathrm{d}$ & $2038.2 \mathrm{~b}$ & $2254.2 \mathrm{~b}$ \\
\hline & \pm S.D. & 361.2 & 327.8 & 45.12 & 413.15 \\
\hline \multirow{2}{*}{$\begin{array}{l}\text { Malonedialdehyde } \\
\text { (n Mol/ml) }\end{array}$} & Mean & 0.602 & $2.04 \mathrm{a}, \mathrm{c}$ & $1.22 \mathrm{a}, \mathrm{b}, \mathrm{d}$ & $2.3 \mathrm{a}, \mathrm{c}$ \\
\hline & \pm S.D. & 0.08 & 0.2 & 0.2 & 0.2 \\
\hline \multirow{2}{*}{$\begin{array}{c}\text { Aspartate } \\
\text { aminotransferase } \\
(\mathrm{U} / \mathrm{L})\end{array}$} & Mean & 174.0 & $267.8 \mathrm{a}, \mathrm{c}, \mathrm{d}$ & $166.8 \mathrm{~b}$ & $164.76 \mathrm{a}, \mathrm{b}$ \\
\hline & \pm S.D. & 4.29 & 2.94 & 4.05 & 3.33 \\
\hline \multirow{2}{*}{$\begin{array}{l}\text { Alanin aminotransferase } \\
(\mathbf{U} / \mathrm{L})\end{array}$} & Mean & 44.6 & $78.32 \mathrm{a}, \mathrm{c}, \mathrm{d}$ & $53.66 \mathrm{~b}$ & $44.9 \mathrm{~b}$ \\
\hline & \pm S.D. & 1.46 & 1.42 & 8.83 & 2.54 \\
\hline
\end{tabular}

Values given as mean of 15 mice $\pm \mathrm{SD}$

(a) Significant at $\mathrm{P}<0.05$ as compared to control group.

(b) Significant at $\mathrm{P}<0.05$ as compared to $\mathrm{CCl} 4$ group.

(c) Significant at $\mathrm{P}<0.05$ as compared to $\mathrm{CCl} 4+$ Vit.A group.

(d) Significant at $\mathrm{P}<0.05$ as compared to $\mathrm{CCl} 4+$ Vit.C group.

Table (2): Histopathological changes in the liver of mice treated with $\mathrm{CCl} 4$ and supplemented with vitamin $A$ and vitamin $C$.

\begin{tabular}{|c|c|c|c|c|c|c|c|c|c|}
\hline \multirow{3}{*}{$\begin{array}{c}\text { Treatment } \\
\text { groups }\end{array}$} & \multicolumn{9}{|c|}{ Histopathological changes } \\
\hline & \multicolumn{3}{|c|}{ Lobular architecture } & \multicolumn{2}{|c|}{$\begin{array}{c}\text { Hydropic } \\
\text { degeneration }\end{array}$} & \multicolumn{2}{|c|}{ Steatotic changes } & \multicolumn{2}{|c|}{ Apoptosis } \\
\hline & No of sp. & $\begin{array}{l}\text { Preserve } \\
\mathrm{d}\end{array}$ & Cirrhosis & $\begin{array}{l}\text { No of } \\
+\mathrm{ve}\end{array}$ & $\begin{array}{l}\text { Mean } \\
\%\end{array}$ & $\begin{array}{l}\text { No of } \\
+\mathrm{ve}\end{array}$ & Mean \% & $\begin{array}{l}\text { No of } \\
+\mathrm{ve}\end{array}$ & Mean \% \\
\hline Control & 5 & $100 \%$ & Non & Non & Non & Non & Non & Non & Non \\
\hline $\mathrm{CCl}_{4}$ & $8 / 15$ & Non & $100 \%$ & $15 / 15$ & $70 \%$ & $8 / 15$ & $75 \%$ & $8 / 15$ & $20 \%$ \\
\hline $\mathrm{CCl}_{4}+\mathrm{Vit} \mathrm{A}$ & $12 / 15$ & $35 \%$ & $65 \%$ & $12 / 15$ & $60 \%$ & $7 / 15$ & $50 \%$ & $4 / 15$ & $10 \%$ \\
\hline $\mathrm{CCl}_{4}+\mathrm{Vit} \mathrm{C}$ & $12 / 15$ & $20 \%$ & $80 \%$ & $10 / 15$ & $70 \%$ & $8 / 15$ & $60 \%$ & $7 / 15$ & $18 \%$ \\
\hline
\end{tabular}

15 animals in each group was investigated, 5 slides per animal and 5 microscopic fields per slide. 
Antioxidative and antiapoptotic effects of.........
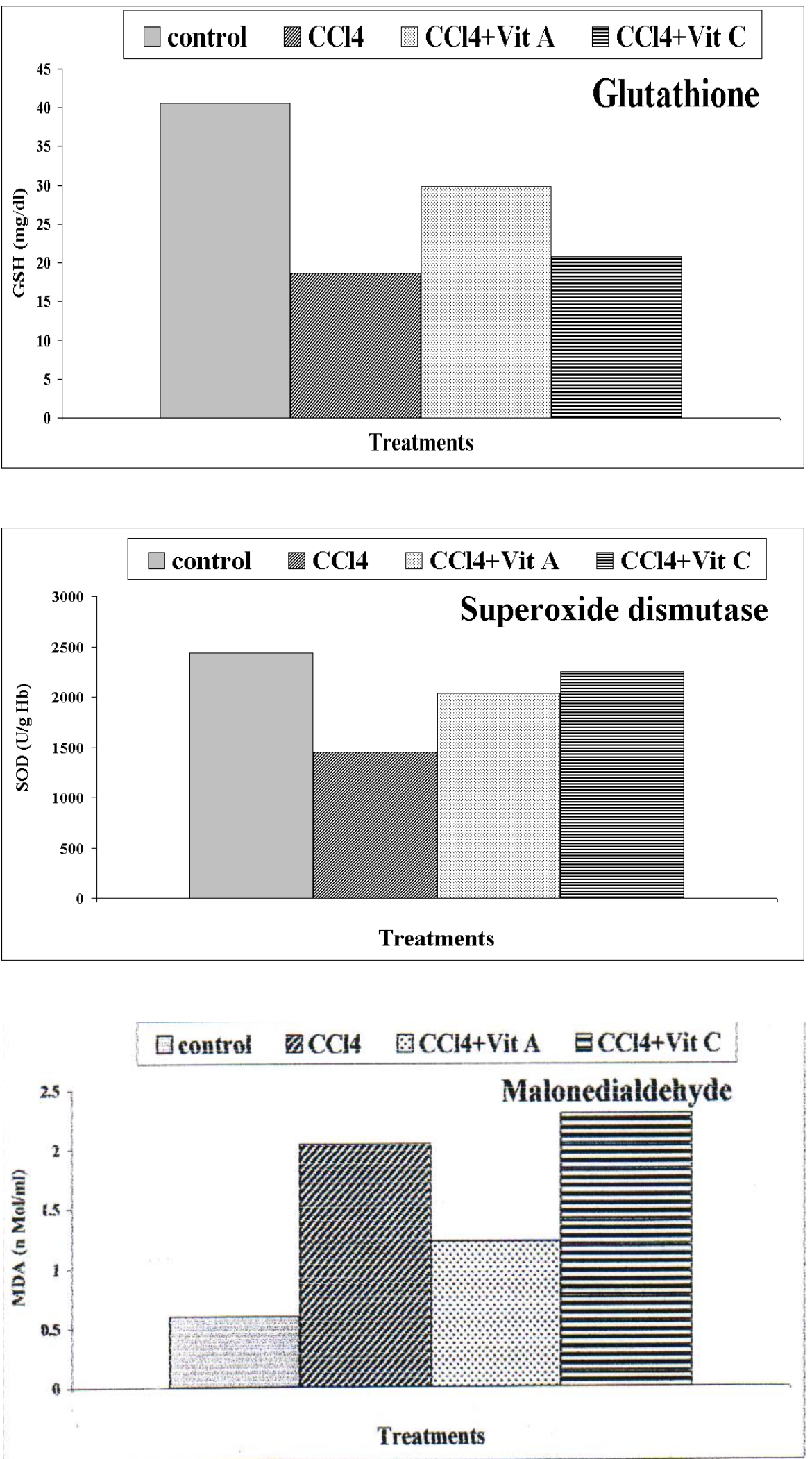

Figure (1): Effect of Carbont etrachloride (CCL4) hepatotoxicity and the possible role of Vitamin A and Vitamin C supplementation on serum Glutathione, blood superoxide dismutase and serum Malondialdehyde of mice. 

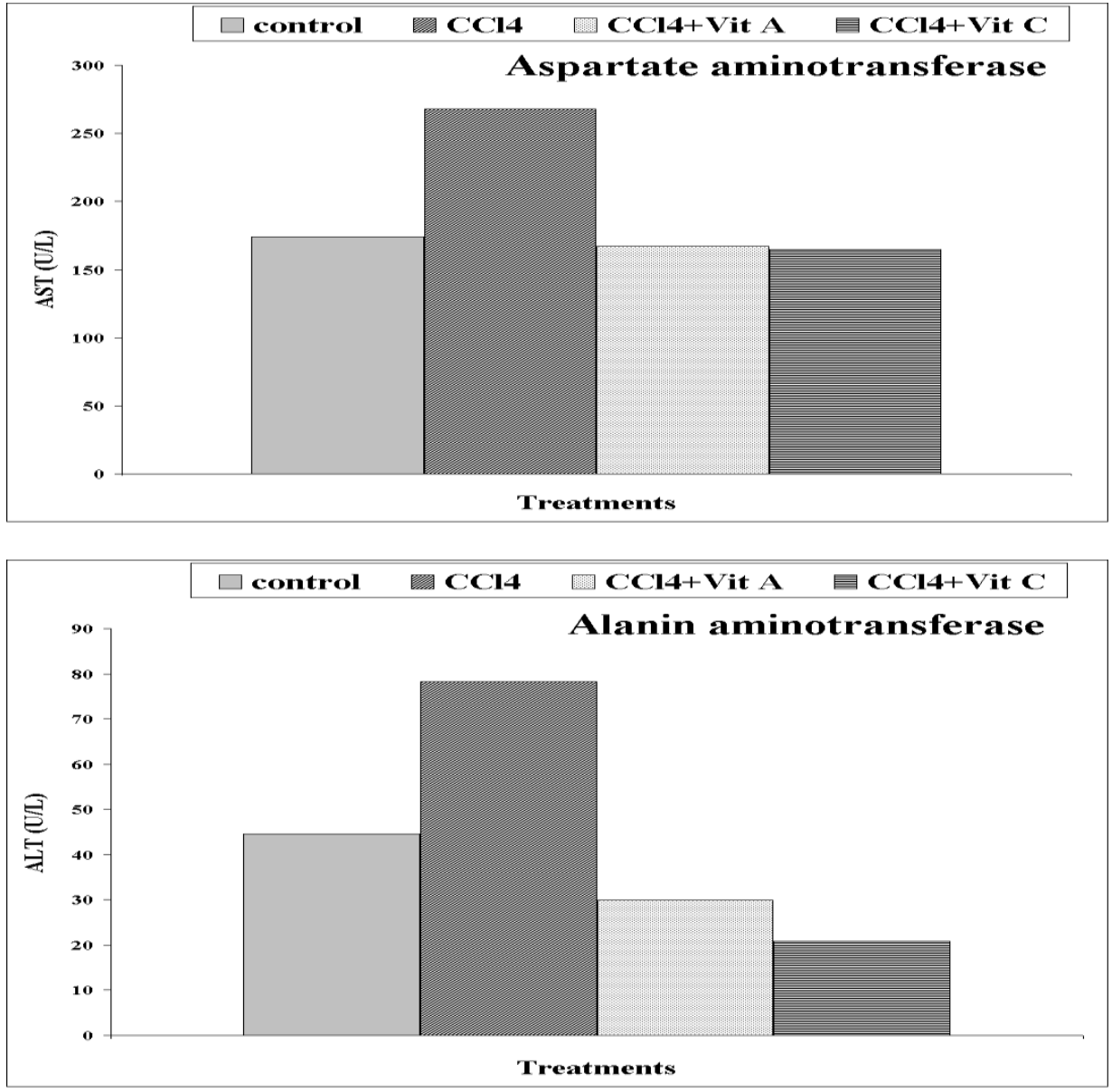

Figure (2): Effect of Carbont etrachloride (CCL4) hepatotoxicity and the possible role of Vitamin A and Vitamin C supplementatio n on Aspartate aminotransferase (AST) and Alanin aminotransferase (ALT) of nice.

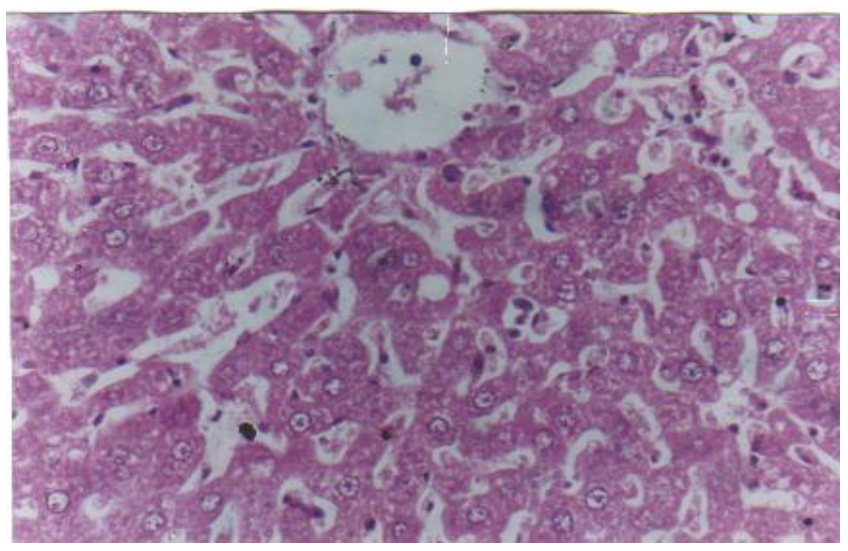

Fig. (3): Histological preparation from non-treated control mouse showing normal hepatic architecture and healthy hepatocytes. X400 


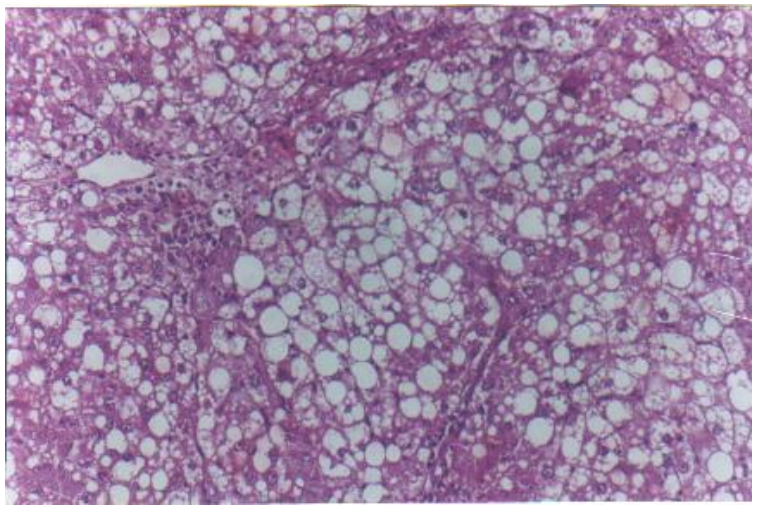

Fig. (4) Section of the liver of mouse treated with $\mathrm{CC} 14$ showing hepatic fibrosis merging into sinusoid cirrhosis, fibrous strands in between hepatocytes and also shows steatoic changes and hydropic degeneration. X 400

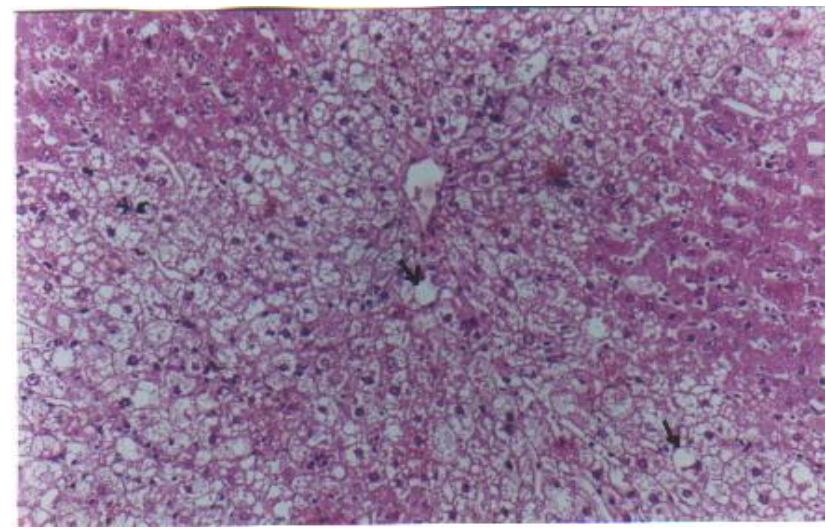

Fig. (5) Section of the liver of mouse treated with CC14 + Vit. A showing variable degree of hydropic degeneration with moderate degree of steatotic changes. X 400

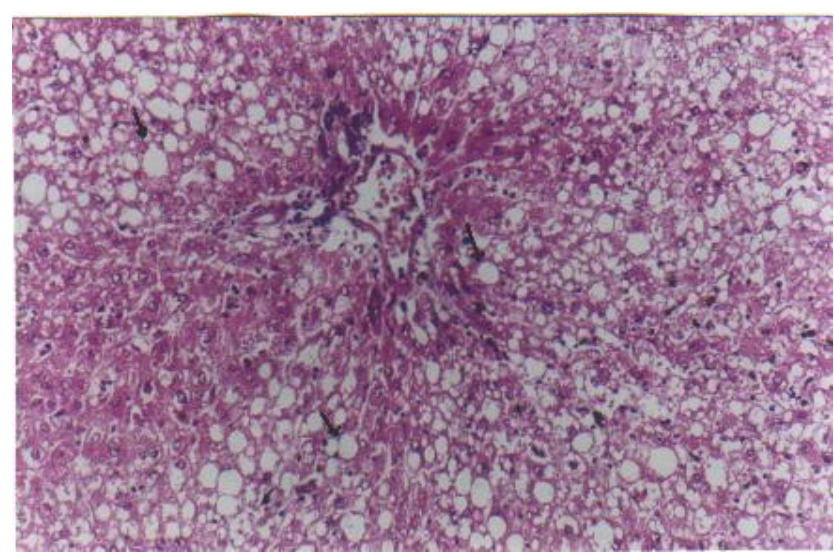

Fig. (5) Section in the liver of mouse treated with CC14 + Vit. C showing steatotic changes $(50 \%)$, hydropic degeneration $(70 \%)$ and area of necrosis. X 400 


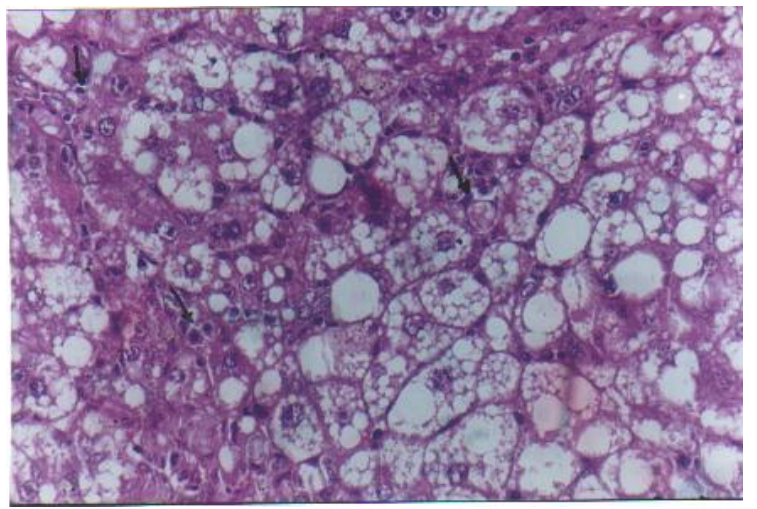

Fig. (7) Section in the liver of mouse treated with CC14 + Vit. A showing few apoptotic cells.

X 400

\section{Discussion}

Treatment with hepatotoxin namely Carbon tetrachloride (CCl4) induced significant alteration in endoge-nous antioxidants activity (Glutathione GSH and Superoxid dismutase SOD), hepatic lipid peroxidation measured as malondialdhyde MDA and serum level of aminotransferases AST \& ALT.

Animals respond to oxidative stress by maintaining a high antioxidant defense capacity at all times including both elevated activities of antioxidant enzymes and large cellular pools of glutathione (Storey, 1996).

The observed significant decrease in serum glutathione level in mice resulted of $\mathrm{CCl} 4$ hepatotoxicity comes in agreement with the finding of El-Khatib and Mansour (2001) and Hewawasam et al. (2003).

Serum Superoxid dismutase (SOD) activity was found reduced significantly by the effect of treatment with $\mathrm{CCl} 4$ in agreement with Adamska et al. (2003).

The cell defense mechanisms against oxygen toxicity increases in liver to suppress oxidative imbalance (Sanz et al., 1996), thus serum GSH and SOD levels were significantly decreased.

A variety of different methods have been used to assess the extent of peroxidative damage to lipids (Halliwell and Chirico, 1993). Some aim to quantify the damage done by peroxidation including the formation of conjugated dienes and of various decomposition products such as malondialdehyde (MDA),lipofuscin, lkenes and light emission by Russel reactions (Slater, 1984; Uchiyama and Mihara, 1978).

The significant elevation in MDA of $\mathrm{CCl} 4$ treated group, which reflect signifycant increase in hepatic lipid peroxidation also comes in agreements with the findings of Mansour (2000) and Perez-trueba et al. (2003).

The marked increase in serum transaminase enzymes activity (AST \& ALT) in $\mathrm{CCl} 4$ treated group was also recorded by many authors (Datta et al, 1998; Mansour, 2000; Al-Katib and Mansour, 2001; Hsiao et al, 2001; Yoshikawa et al, 2002; Hsiao et al, 2003 and Hewawasam et al, 2003).

Treatment with Vitamins A \& C were found greatly effective in restoring the values of serum GSH, SOD, MDA, AST and ALT to normal which may be due to free radical scavenging properties of both vitamins.

The results show that vitamin $\mathrm{A}$ was found more effective than vitamin $\mathrm{C}$ in preventing the dramatic drop in serum GSH level by the effect of $\mathrm{CCl} 4$ hepatotoxicity. It was also more powerful in preventing the enhancing of lipid peroxidation which appear in keeping low values of MDA compared to its values in vitamin $\mathrm{C}$ treated group.

Some authors studied Cytoprotection against CCl4-induced hepatotoxicity using different antioxidants. Mansour (2000) 
referred the protective effects of Thymoquinone and Desferrioxamine to inhibition of the production of oxygen free radicals that cause lipid peroxidation. El-Khatib and Mansour (2001) revealed that the protective potential of Captopril against the acute hepatotoxicity induced by $\mathrm{CCl} 4$ in mice could be attributed at least in part to the free radical scavenging properties of the drug, Vitamin $\mathrm{C}$ and Vitamin $\mathrm{E}$ was recorded effectively restored the elevated levels of primary and secondary products of lipid peroxidation in mice (Tantcheva et al., 2003). Ascorbic acid exerts its protective role probably mediated via a free radical scavenging mechanism (Hasan et al., 2003). Hsiao (2001) suggested that PMC, (a derivative of alphatocopherol) exerts effective protection in chronic chemical induced hepatic injury in vivo.

In the other hand, in their comprehensive report on the dietary reference intake for vitamin $\mathrm{C}$, vitamin $\mathrm{E}$, selenium and carotenoids Johnson et al. (2003) did not decisively confirmed the role of antioxidants for the prevention of chronic diseases in human. They recommended additional research to define the attributes of antioxidants as studies are in progress progress from in vitro and animal studies to human nutrition.

$\mathrm{CCl} 4$ intoxication induced severe histopathological alterations in the liver of mice including great loss of lobular architecture, cirrhoses, hydropic and steatotic changes and finally apoptosis. Similar results were observed by Turkdo et al. (2001) in rabbits and Nakamoto et al. (2003) in rats. The observed partial improvement in the previous parameters in the groups treated with $\mathrm{CCl} 4+$ Vit.A and $\mathrm{CCl} 4+$ Vit.C reflect the antioxidative and cellular protective effect of vitamin A\&C although vitamin A seemed to be more effective than vitamin C.

It was recorded that Retinoic acid (RA), a form of vitamin A, has been shown to exert antiapoptotic and antioxidative activity in various cells (Shimizu et al 2001). They suggested that RA reduced $\mathrm{CCl} 4$ induced oxidative stress and cell death by preventing the decrease in protein levels of superoxide dismutase $1 \& 2$ thus supporting the antioxidant defense system. In contrast, in his study on the role of antioxidant vitamins (C and $\mathrm{E}$ ), selenium and Nigella sativa in the prevention of $\mathrm{CCl} 4$ induced liver fibrosis and cirrhosis in rabbit, Turkdo et al (2003) reported that histopathological findings demonstrate that vitamin $\mathrm{C}$ seemed to be ineffective in prevention of $\mathrm{CCl} 4$ liver fibrosis and cirrhosis in rabbits.

In conclusion our results theorized that vitamin A \& $\mathrm{C}$ may have a potency to increase the antioxidant and antiapoptotic defense system activity in the $\mathrm{CCl} 4$ treated mice.

\section{References}

1. Adamska T, Mlynarczyk W, JodynisLiebert J, Bylka W and Matlawska I (2003): Hepatoprotective effect of the extract and isocytisoside from Aquilegia vulgaris. Phytother Res. 17(6): 691-6.

2. Begonia RL, Leal AM, Liza M, Lacert M and Degroot $H$ (1994): Antioxidant effects of estradiol and 2-dehydroxy estradiolon iron-induced lipid peroxidation of rat liver micro-somes. Steroids 59: 383.

3. Beutler E, Duron $O$ and Kelly BM (1963): Improved method for the determination of blood glutathione. J. Lab. Clin. Med. 61: 882.

4. Datta S, Basu K, Sinha $S$ and Bhattacharyya P (1998): Hepatoprotective effect of a protein isolated from Cajanus indicus (Spreng) on carbon tetrachloride induced hepatotoxicity in mice. Indian J Exp Biol. Feb. 36(2): 175-81.

5. El-Khatib AS and Mansour MA (2001): Prior treatment with captopril attenuates carbon tetrachloride-induced liver injury in mice. Res Commun Mol Pathol Pharmacol. Jul-Aug. 110(1-2): 3-16.

6. Halliwell B. and Chirico S (1993): Lipid peroxidation: its mechanism, measurement, and significance. Am. J. Nutr.57(suppl), 715S-725S

7. Hasan MY, Alshuaib WB, Singh S and Fahim MA (2003): Effects of ascorbic acid on lead induced alterat-ions of synaptic transmission and contr-actile features in murine dorsiflexor muscle. Life Sci. 73(8): 1017-25.

8. Hsiao G, Lin YH, Lin CH, Chou DS, Lin WC and Sheu JR (2001): The protective effects of PMC against chronic carbon 
tetrachloride-induced hepatotoxicity in vivo. Biol Pharm Bull. 24(11): 1271-6.

9. Hsiao G, Shen MY, Lin KH, Lan MH, Wu LY, Chou DS, Lin CH and Sheu JI (2003): Antioxidative and hepatoprotective effects of Antrodia camphorata extract. J Agric Food Chem. 51(11): 3302-8.

10. Hewawasam RP, Jayatilaka KA, Pathirana C and Mudduwa LK (2003): Protective effect of Asteracantha longifolia extract in mouse liver injury induced by carbon tetrachloride and paracetamol. J. Pharm Pharmacol. 55(10): 1413-8.

11. Johnson LJ, Meacham SL and Kruskall LJ (2003): The antioxid-ants-vitamin C, vitamin E, selenium, and ca-rotenoids. J Agromedicine. 9(1): 65-82.

12. Kamataki T, Sugita O, Kitada $M$, Naminohira S and Kitagawa H (1977): Induction of carbon tetrach loride of a lipid peroxidation inhibitor (LPI) present in rat liver soluble fract ion. Res Commun Chem Pathol Pharmacol. 17(2): 265-73.

13. Mansour MA (2000): Protective effe-cts of thymoquinone and desferrio-xamine against hepatotoxicity of carbon tetrachloride in mice. Life Sci. 66(26): 2583-91.

14. Mansour Ma, Ginawi OT, El-Hadiyah T, El-Khatib AS, Al-ShabanahOA and AlSawaf HA (2001): Effects of volatile oil constitu-ents of Nigella sativa on carbon tetrac-hloride- induced hepatotoxicity in mice: evidence for antioxidant effects of thy-moquinone. Res Common Mol Pathol Pharmacol 110(3-4): 239-51.

15. Mizuoka H, Shikata N, Yang J, Takasu $M$, Inoue $K$ and Tsubura A (1999): Biphasic effect of colchicines on acute liver injury induced by carbon tetrachloride or by dimethylnitrosamine in mice. J Hepatol. 31(5): 825-33.

16. Mustafa Naziroglu, Mehmet C, Bilal U, Mesut A and Hayrettin Y (1999): Protective effects of vitamin E on carbon tetrachloride-induced liver damage in rats. Cell Biochem. Funct. 17: 253-259.

17. Nakamoto N, Tada S, Kameyama $K$, Kitamura K, Kurita S, Saito Y, Saito H and Ishii $H$ (2003): A free radical scavenger, edaravone, attenuates steato-sis and cell death via reducing inflam-matory cytokine production in rat acute liver injury. Free Radic Res. 37(8): 849-59.

18. Perez-Trueba G, Ramos-Guanche C, Martinez-Sanchez B, MarquezHernandez I, Giuliani A and MartinezSanchez G (2003): Protective effect of
Gossypitrin on carbon tetrachlorideinduced in vivo hepatotoxicity. Redox Rep. 8(4): 215-21.

19. Reitman S. and Frankel S. (1957): Acolourmetric method for the determination serum glutamic oxaloacetic and gluatmic pyrovate transaminase Am. J. Clin. Path., 28: 56-60.

20. Sanz N; Diez-Fermandez $C$ and Cascales M (1996): Varaitions of hepatic systems and DNA ploidy in rats aged 2 to 8 months. Biophysica Acta 1315,123.

21. Shimizu, Igarashi, Ohtuka, Oguchi, Kaneko and Yamashiro (2001): Effect of n-3 polyunsaturated fatty acids and vitamin $\mathrm{E}$ on colonic mucosal leukotriene generation, lipid peroxid-ation and microcirculation in rats with experimental colitis. Digestion 63(1): 43-48.

22. Slater TF. (1984): Overview of methods used for detecting lipid peroxi-dation. Meth. Enzymol. 105: 283-293.

23. Storey KB. (1996): Oxidative stress: Animal adaptations in nature. Brazilian J. Med. Biol. Res. 29: 1715-1733.

24. Tantecheva LP, Stoeva ES, Galabov AS, Brykova AA, Savov VM and Mileva MM. (2003): Effect of vitamin $E$ and vitamin $\mathrm{C}$ combination on exp-erimental influenz virus infection. Methods Find Exp Clin Pharmacol. 25(4): 259-64.

25. Turkdo A, Ayan MK, AA, AyaoA, Aylu Z, Yener Z, SekeroA, Aylu R, Akkan HA and Avci ME. (2001): The role of antioxidant vitamins ( $\mathrm{C}$ and $\mathrm{E}$ ), selenium and Nigella sativa in the prevention of liver fibrosis and cirrhosis in rabbits: new hopes. Dtsch Tierarztt Woche-nschr. 108(2): 71-3.

26. Uchiyama, M. and Mihara, M. (1978): Determination of malonaldehyde in tissues by thiobarbituric acid test. Anal. Biochem. 86: 271-278.

27. Wang DQ, Ding BG, Ma YQ, Zhao HL, Neil TG, Brian T, Tian YP, Wang CB and Critchley JA (2001): Studies on protective effect of total flavonoids of Astragalus on liver dam-age paracetamolinducedby. Zhongguo Zhong Yao Za Zhi 26(7): 483-6.

28. Yoshikawa M, Ninomiya K, Shimoda H, Nishida N. and Matsuda, H. (2002): Hepatoprotective and antioxidative properties of Salacia reticulata: preventive effects of phenolic constituents on $\mathrm{CCl}$ induced liver injury in mice. Biol Pharm Bull 25(1): 72-6. 


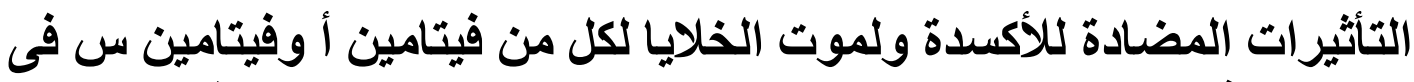

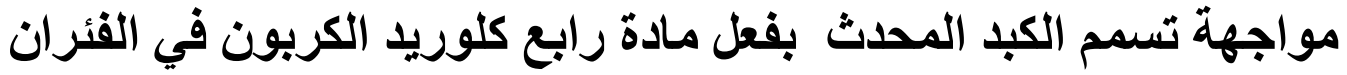

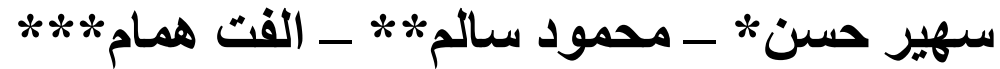

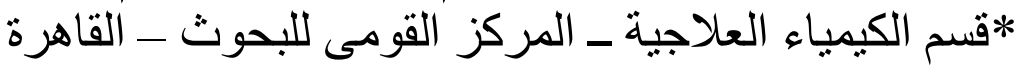

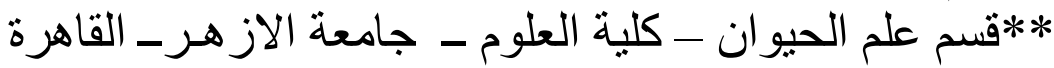

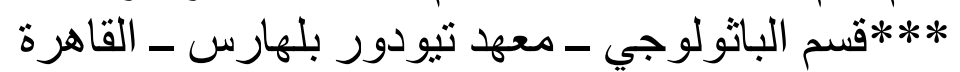

تلعب قو اعد الأكسجين النشطة دور الهاما في احداث مختلف انماط اصابات الكبد. وقد

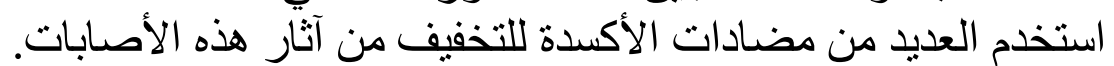

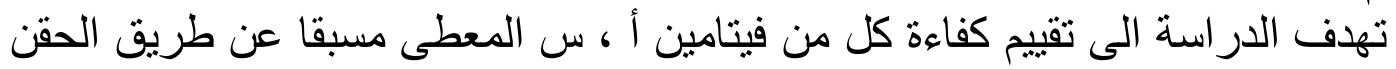

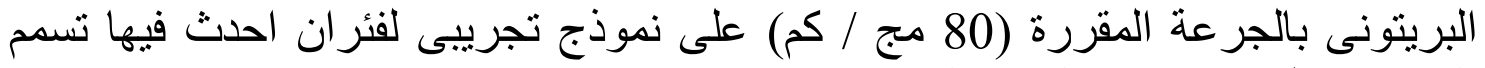

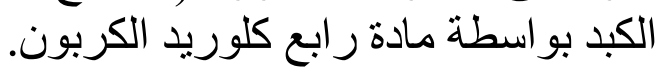

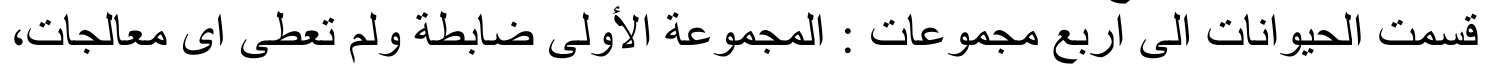

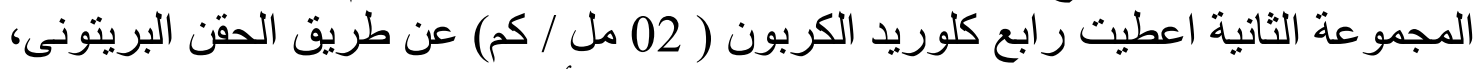

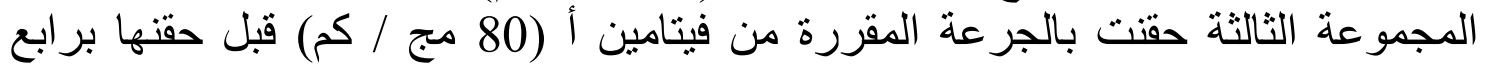

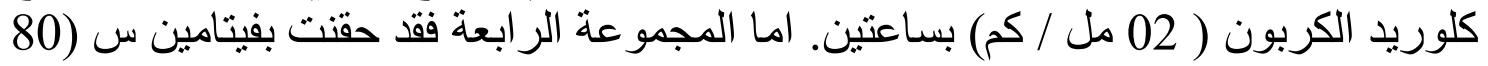

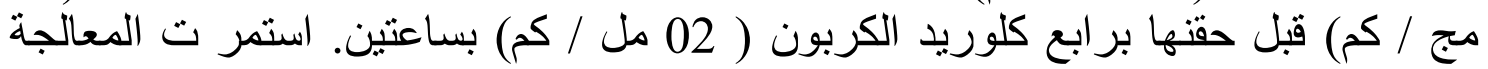

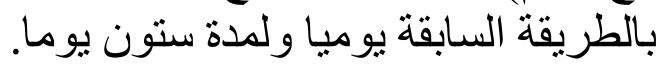
اظهرت النتائج انخفاض ملحوظة فئا فى نسبة الجلوتاثيون وكذللك انزيم سوبر اكسيد

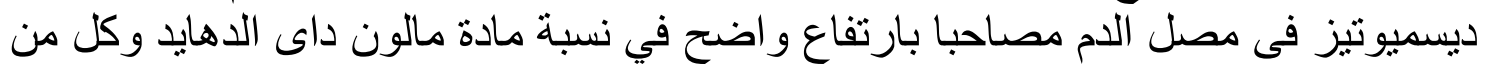

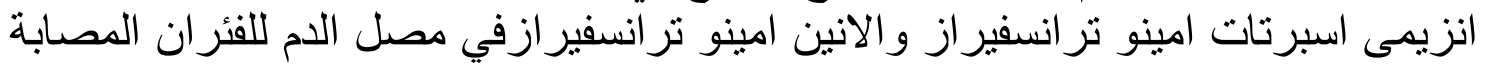

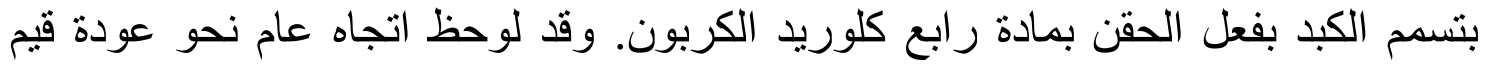

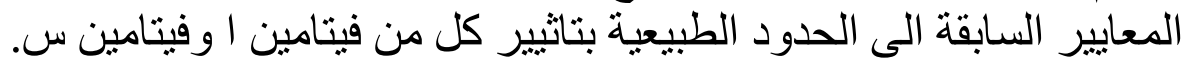

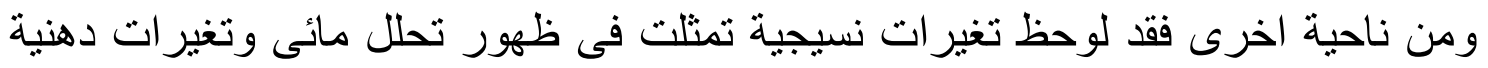

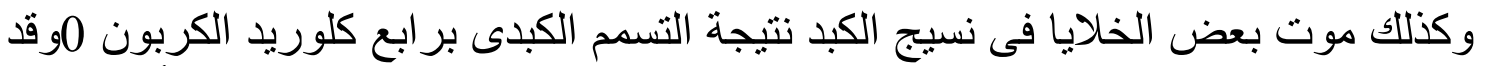

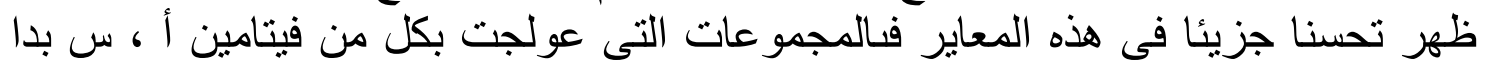

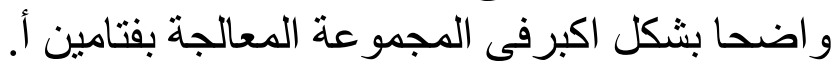

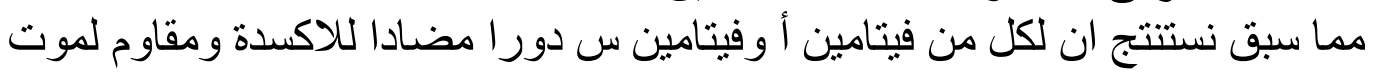
الخلايا فى كبد الفئران المعرضة انسية لسمية رابع كلوريد الكربين 